Walisongo Law Review (Walrev), Vol 2 No. 2 (2020)

DOI: 10.21580/Walrev/2020.2.2.6850

Copyright (C) 2020 Walisongo Law Review (Walrev)

\title{
Sociological Aspects of Judges in Granting Applications for Marriage Dispensation (Study of Determination Number: oo38/Pdt.P/2014/PA.Pt)
}

\section{Arina Hukmu Adila}

Afiliasi: Universitas Islam Negeri (UIN) Walisongo, Semarang

Email: arinadila18@gmail.com

\begin{abstract}
Many children have a pregnancy out of wedlock. Many factors make the parents marry off their underage children who are pregnant out of wedlock, by applying for matrimonial dispensation to the Religious Courts. Law Number 1 Year 1974 on Marriage has set a minimum age limit for men and women to marry with age and psychological maturity considerations, for the realization of the purpose of the marriage. This study uses a juridicalempirical method, which will see the Religious Courts as the authorized institution, having particular considerations in granting marriage dispensation applications in order to fulfill the rights of the people and to preserve the order of life in the community.
\end{abstract}

Banyak terjadi anak-anak mengalami kehamilan di luar nikah akibat dari pergaulan yang terlalu bebas antara lakilaki dan perempuan. Banyak faktor yang membuat orang tua menikahkan anaknya yang masih di bawah umur yang 
Arina Hukmu Adila, Sociological Aspects of Judges...

hamil di luar nikah, yakni dengan mengajukan permohonan dispensasi kawin ke Pengadilan Agama. Undang-undang Nomor 1 Tahun 1974 tentang Perkawinan telah menentukan batas usia minimum bagi laki-laki dan perempuan untuk menikah dengan pertimbangan kematangan usia dan psikologis, demi terwujudnya tujuan pernikahan tersebut. Penelitian ini menggunakan metode yuridis-empiris, yang akan melihat Pengadilan Agama sebagai lembaga yang berwenang, memiliki pertimbangan-pertimbangan tertentu dalam mengabulkan permohonan dispensasi kawin dengan tujuan untuk memenuhi hak-hak masyarakat.

Keywords: Marriage; Matrimonial Dispensation; Underage Marriage.

\section{Introduction}

In the millennial era, which is a digital era, everyone can access anything through their devices, including teenagers and minors. The borderless digital world gives teenagers and children wide access to pornographic things, which makes them overwhelmed with curiosity until they finally try to do things that are not commonly done by their age, such as having sex like husband and wife. As a result, there are many cases of pregnancy outside of marriage.

Facing this condition, both parents and spouses of children who became pregnant outside of wedlock responded differently. There are those who choose to abort the womb, hide it from their parents, to lose the baby's life resulting from an affair. However, it is not uncommon for parents to choose to marry off their children to their partners in order to maintain family dignity so as not to endure shame. Because the age of the child is still a minor, parents need to apply for dispensation to marry the Religious Court. The judge also did not automatically grant the request for dispensation of marriage from the child's parents. Many factors are considered by the judge in granting a marriage dispensation request.

The court as the representative of the law, -where the judge does his job- plays a very important role in the law enforcement system. From a social perspective, the court must be seen as a social 
institution that will interact with other social institutions (Suteki 2013:208-209).

When applied in the theory of "Law as an Integration Mechanism" by Harry C. Bredemeier, it can be explained that the functioning of judges in deciding cases is influenced by 3 input factors, namely economic and science and technology factors, political factors, and cultural factors. Satjipto Rahardjo said that judges in carrying out their work are disciplined by expected reactions (hopes and demands of community members). Judges are surrounded by the hopes and demands of members of society organized around the duties of the judge (although de jure, judges have freedom in deciding cases) (Rahardjo 2010; Suteki 2013:209-211).

The author looks at previous studies regarding marriage dispensation using the normative juridical method, for example in the research of Nafi 'Miswar (2011) entitled Marriage Dispensation due to extramarital relations (Study of Judges at the Tuungagung Religious Court in 2010), IAIN Tulungagung; Akhmad Mu'arif (2014) entitled Rejection of Marriage Dispensation (Study on the Judge of the Pemalang Religious Court Number: 0010/Pdt.P/2013/PA.Pml), STAIN Pekalongan; Dwi Idayanti (2014) entitled Granting Marriage Dispensation by the Religious Court (Case Study at the Kotamobagu Religious Court), Sam Ratulangi University, Manado; Kamelia Sari (2015) entitled the Stipulation of the 2012-2014 Marriage Dispensation Request (Study at the Rengat Religious Court of Riau Province), Syarif Hidayatullah University Jakarta.

In this study, the authors tried to look at this problem using the juridical-empirical method. Not only in terms of statutory regulations, but more inclined towards the sociological aspects of the judge in granting applications for dispensation of marriage (Soekanto 1982). Because dispensation of marriage is a solution related to urgent matters in the form of minors who have become pregnant out of wedlock so that they and their children who are born later can get their rights, and also to avoid public gossip as a result of this dishonorable act.

From the description above, the problems that can be arranged include, why is there a request for dispensation of marriage? and what 
factors are considered by the judge in granting a marriage dispensation request?

This research uses the juridical-empirical method, which is a type of legal research that functions to see the law in a real sense, in this case regarding how the judge determines a marriage dispensation case (Marzuki 2016; Soemitro 1990). The research specification of this article is descriptive-analytical. The types and techniques of data collection in this study were initially examining secondary data, and then continued with research on primary data in the field. The data analysis method used is the juridical analysis method.

\section{Application for Dispensation of Marriage}

As the author mentioned above, applications for dispensation of marriage are often made because the girl is pregnant out of wedlock due to her relationship with her partner. However, getting pregnant outside of marriage is not the only reason. The factor of the child's closeness to his or her partner who is too close often makes parents worry so that in order to prevent adultery or unwanted things, parents decide to marry their child (Harun 2019; Rofiq 2018; Zuhri 2019). Of course, the decision to marry off was without coercion to the child and was accompanied by the willingness of the child and his partner.

Basically, marriage is a physical and mental bond between a man and a woman as husband and wife with the aim of forming a happy and eternal family or household based on the One Godhead (Pemerintah Republik Indonesia 1974:Article 4). For this reason, Law Number 1 of 1974 concerning Marriage also regulates the minimum limit for a person to be allowed to marry, namely the age of 19 (nineteen) years for men, and 16 (sixteen) years for women (Pemerintah Republik Indonesia 1974:Article 7 (1)). This article contains several principles to ensure the noble ideals of marriage, namely voluntary principles, family participation, and maturity of the prospective bride and groom (physical and mental maturity of the prospective bride) (Zubaidah 2017).

Age can be a benchmark for a person's maturity level, although not absolutely. At these ages it can be interpreted that a person has 
reached maturities: (1) Biological maturity, (2) Economic maturity, (3) Social maturity education maturity (Mu'arif 2014:20).

In cases of pregnancy outside of wedlock that occur to minors, applications for dispensation of marriage are a solution for their parents. The reasons for choosing to apply for dispensation of marriage, among others: (1) The relationship between the Petitioner's child (parents) and their spouse is already close and difficult to separate, (2) the Petitioner's child is pregnant, (3) the Petitioner is worried that things will happen again. - things that violate Islamic law if they are not married immediately.

Applications for dispensation of marriage if the prospective bride is pregnant is allowed. This is based on the provisions of Article 53 of the Compilation of Islamic Law where a pregnant woman out of wedlock can be married to a man who impregnated her. Marriages with pregnant women can be carried out without waiting for the birth of their child first. Furthermore, by taking place when a woman is pregnant, remarriage is not required after the child is born (Imron 2011, 2017; Rismana 2019).

On the other hand, the choice to marry off the child is to maintain the dignity of the family and to prevent the family from feeling embarrassed by the act.

\section{Judge's Consideration to Grant}

In doing their job, the Court, especially the judge will be influenced by factors that are outside and inside the institution. Internal factors include human resources, organizational governance, work environment culture, material resources (economy), management systems, leadership, and others. External factors can be in the form of interactions between other law enforcement agencies and the community as users of court services (Suteki 2013:208).

The court as the representative of "law", - where the judge does his job - plays a very important role in the law enforcement system. From a social perspective, the court must be seen as a social institution that will interact with other social institutions (Suteki 2013:208-209).

When applied in the theory of "Law as an Integration Mechanism" by Harry C. Bredemeier, it can be explained that the functioning of 
judges in deciding cases is influenced by 3 input factors, namely economic and science and technology factors, political factors, and cultural factors (Nurdin 2015; Suteki 2013:209). Satjipto Rahardjo said that judges in carrying out their work are disciplined by expected reactions (hopes and demands of community members) (Rahardjo 1991). Judges are surrounded by the hopes and demands of members of society organized around the duties of the judge (although de jure, judges have freedom in deciding cases).

Theory "Law as an integration mechanism Harry C. Bredemeier

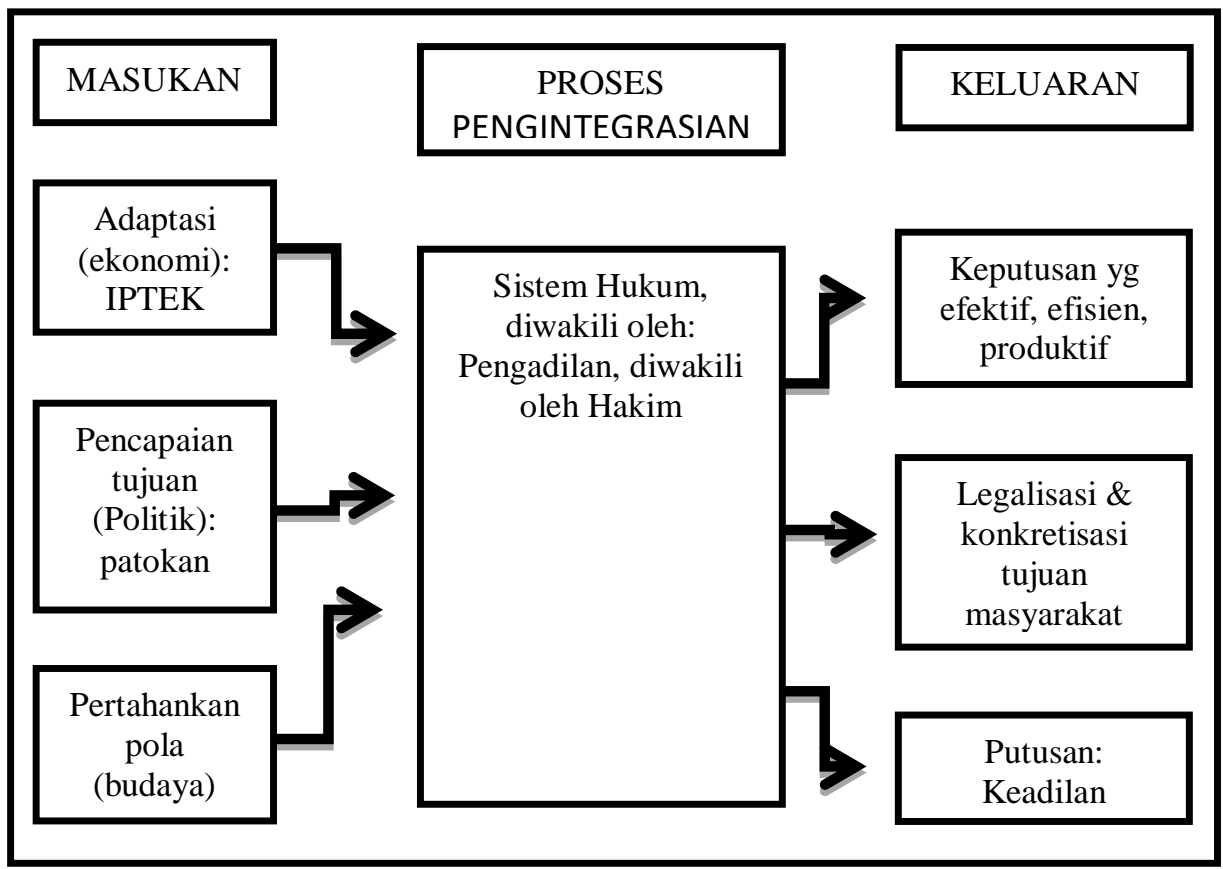

Law Number 1 of 1974 concerning Marriage does regulate the minimum limit for a person to be allowed to marry, namely the age of 19 (nineteen) years for men, and 16 (sixteen) years for women. In addition, determining the age limit for marriage is an effort to guarantee the maturity of a married couple. Armed with maturity in terms of age, it is hoped that they will be able to give birth to a harmonious family order that is dreamed by every husband and wife. 
The author is of the opinion that this provision is in line with the provisions of Article 26 Paragraph (1) letter c of Law Number 23 Year 2002 concerning Child Protection which states that parents are obliged and responsible to prevent marriage at the age of children. However, in reality, as described above, in society, there are many cases of pregnancy outside of marriage that occur in minors. So that the dispensation of marriage is a solution to this urgent condition considering that if a marriage is not carried out, it will have an impact on the social and psychological life of the child, and will raise new problems, namely regarding the legal status of children born outside of marriage where their rights as children are not fully fulfilled. and the possibility of gossip in society is inevitable.

The decision to apply for dispensation for marriage is also still in line with the principle of non-discrimination and the principle of the best interests of the child as stipulated in Article 2 of Law Number 23 Year 2002 concerning Child Protection.

In Determination Number: 0038 / Pdt.P / 2014 / PA.Pt, the judge of the Pati Religious Court granted the request for dispensation to the parent's marriage with the following legal considerations: (1) That the Petitioner's child who is 14 years 2 months old is pregnant 3 (three) months, (2) That there are parents' concerns about the condition of their child which is closely related to their close friends, especially if the child is pregnant, (3) There is shame experienced by parents and it becomes public gossip and disgrace if the child is already pregnant not immediately being married, (4) The situation as mentioned above is considered an urgent disaster to find a way out of slander and to achieve a sense of comfort in social life (Adila 2017).

Thus, judges in deciding a case are not in a vacuum. Non-legal aspects also influence or become consideration for judges in seeking restorative justice for the community.

\section{Conclusion}

The reasons for choosing to apply for dispensation of marriage, among others: (1) The relationship between the Petitioner's child (parents) and their spouse is already close and difficult to separate, (2) the Petitioner's child is pregnant, (3) the Petitioner is worried that 
things will happen again. -things that violate Islamic law if they are not married immediately.

The Judge of the Pati Religious Court in Determination Number: 0038 / Pdt.P / 2014 / PA.Pt granted the request for dispensation to the parent's marriage with legal considerations as follows: (1) That the Petitioner's child who is 14 years 2 months old is pregnant 3 (three) months, (2) Whereas there are parents' concerns about the condition of their child which is so closely related to their close friends, especially if the child is pregnant, (3) There is shame experienced by parents and it becomes public gossip and disgrace if the child who is already pregnant is not immediately being married, (4) The situation as mentioned above is considered an urgent disaster to find a way out of slander and to achieve a sense of comfort in social life. [w]

\section{Reference}

Adila, Arina Hukmu. 2017. "Inteview with Kholis."

Harun, Muhammad. 2019. "Philosophical Study of Hans Kelsen's Thoughts on Law and Satjipto Rahardjo's Ideas on Progressive Law." Walisongo Law Review (Walrev) 1(2):195.

Imron, Ali. 2011. "Dispensasi Perkawinan Perspektif Perlindungan Anak." QISTIE 5(1).

Imron, Ali. 2017. "Rekonstruksi Hukum Putusnya Perkawinan Dalam Undang-Undang Perkawinan.” QISTIE 10(1).

Marzuki, Peter Mahmud. 2016. Penelitian Hukum Edisi Revisi. 12th ed. Jakarta: Kencana Prenada Media.

Mu'arif, A. 2014. Penolakan Dispensasi Nikah (Studi Penetapan Hakim Pengadilan Agama Pemalang Nomor: oo1o/Pdt.P/2013/PA.Pml). Pekalongan: STAIN Pekalongan.

Nurdin, Nazar. 2015. "Anakku Bukan Anak Haram.” Kompas.Com. Retrieved

(https://regional.kompas.com/read/2015/o6/17/12315821/.Ana kku.Bukan.Anak.Haram..?page=all).

Pemerintah Republik Indonesia. 1974. "Undang-Undang No. 1 Tahun 
1974 Tentang Perkawinan.”

Rahardjo, Satjipto. 1991. Ilmu Hukum. Bandung: Citra Aditya Bakti.

Rahardjo, Satjipto. 2010. Penegakan Hukum Progresif. Jakarta: Kompas.

Rismana, Daud. 2019. "Penyuluhan Kesadaran Hukum Tentang Regulasi Alasan Perceraian Dalam Hukum Perkawinan Islam Bagi Keluarga Penerima Manfaat (KPM) Program Keluarga Harapan (PKH) Di Kabupaten Grobogan.” Dimas: Jurnal Pemikiran Agama Untuk Pemberdayaan 19(2):119-30.

Rofiq, M. Khoirur. 2018. "Pencatatan Perkawinan Dalam Istimbath Hukum Islam Dan Hukum Positif Indonesia." An-Nawa: Jurnal Studi Islam.

Soekanto, Soerjono. 1982. Pengantar Penelitian Hukum. Jakarta: UI Press.

Soemitro, Ronny Hanitijo. 1990. "Metodologi Penelitian Hukum Dan Jurimetri." Ghalia Indonesia, Jakarta 167.

Suteki. 2013. Desain Hukum Di Ruang Sosial. Yogyakarta: Penerbit Thafa Media.

Zubaidah, St. 2017. "Dispensasi Kawin Dalam Tinjauan UndangUndang Nomor 23 Tahun 2002 Tentang Perlindungan Anak." Retrieved (https://pa-purworejo.go.id/web/dispensasi-kawindalam-tinjauan-uu-no-23-tahun-2002/).

Zuhri, M. F. 2019. "Forgiveness of Judges: Local Wisdom in the Concept of National Criminal Law." Walisongo Law Review (Walrev) 1(1). 